\title{
An Overview of the Utilization of TikTok to Improve Oral English Communication Competence among EFL Undergraduate Students
}

\author{
Zhai Xiuwen*, Abu Bakar Razali \\ Faculty of Educational Studies, Universiti Putra Malaysia (UPM), Serdang, Malaysia
}

Received April 4, 2021; Revised May 20, 2021; Accepted June 15, 2021

\section{Cite This Paper in the following Citation Styles}

(a): [1] Zhai Xiuwen, Abu Bakar Razali , "An Overview of the Utilization of TikTok to Improve Oral English Communication Competence among EFL Undergraduate Students, "Universal Journal of Educational Research, Vol. 9 , No. 7, pp. 1439 - 1451, 2021. DOI: 10.13189/ujer.2021.090710.

(b): Zhai Xiuwen, Abu Bakar Razali (2021). An Overview of the Utilization of TikTok to Improve Oral English Communication Competence among EFL Undergraduate Students. Universal Journal of Educational Research, 9(7), 1439 - 1451. DOI: 10.13189/ujer.2021.090710.

Copyright $\bigcirc 2021$ by authors, all rights reserved. Authors agree that this article remains permanently open access under the terms of the Creative Commons Attribution License 4.0 International License

\begin{abstract}
The field of English language communication competence learning and acquisition has been revolutionized by the increasing development of technology. The application of social media has now been popular inside and outside of the English language classrooms. The development of technology in the past fifty years, the more recent mobile devices and the Web 2.0 technology have provided numerous opportunities for its use in improving English communication competence. TikTok, one of the popular social media platforms among Chinese international undergraduate students, is now playing an interesting role in their English communication competence learning during Covid-19 pandemic because TikTok supplies English videos with popular topics among youngsters. However, very few studies have been conducted on the utilization of TikTok on EFL undergraduate students' English communication competence. Therefore, this paper aims to explore the potential on the utilization of TikTok and how it impacts on English language communication competence acquisition among Chinese international undergraduate students by reviewing previous and recent studies focusing on TikTok as well as other social medias such as Facebook, YouTube, WeChat and so on. It is important to note that even though previous relevant studies have showcased the positive effects of using social media as learning aids in English language communication acquisition, very few literatures having been published focusing on the utilization of
\end{abstract}

TikTok in English language communication acquisition. The expected findings of this paper could reveal the potential of using TikTok for international undergraduate Chinese students out of EFL classroom in improving their English Communication Competence and for increasing their interests of speaking English. The researchers showcase critical views, recommendations, as well as implications for the utilization of TikTok in the field of English language communication competence acquisition among EFL undergraduate students.

Keywords Social Media Application, TikTok, EFL, Undergraduate Students

\section{Introduction}

For EFL undergraduate students, one of the prominent motivations of studying in English-speaking countries is to improve their English communication competence as for English education in China is grammar-based for examination purpose [18]. In accordance with the Communication Competence theory proposed by Hymes [20], it is significant for English language learners to be immersed in English exposure settings to improve their English communication competence. However, the widespread pandemic of COVID-19 has brought 
unprecedented challenges to English language communication competence acquisition faced by EFL undergraduate students from face to face in the host-country study to online-learning. International education has been shaped by the unexpected outbreak of Covid-19 pandemic [27].In fact, UNESCO (2020) posited that the closure of higher education institutions for the sake of online education and remote teaching have generated diverse negative impacts on international students' academic lives and study-abroad motivations as well as decrease the chances of EFL international students to use English for communication [36].

Fortunately, the development of Web-2.0, as well as the computer technology, has the potential to assist this cohort of EFL learners to be self-regulated learners to improve their English communication competence via short videos posted by some English teachers as well as native-English speakers utilizing social-media platform through interactive learning in English language settings with popular topics among youngsters. For people, social media platforms share information as well as knowledge and skills with short-videos, which plays increasing prominent educational roles in the covid-19 pandemic among youngsters [31].The utilization such as short-video social media mobile applications in English language communication competence acquisition can help generate the natural English communication settings for EFL learners [1].

During the Covid-19 pandemic, social media platforms integrated with short videos have been playing a more and more critical role in English communication competence education among youngsters as the closure of the campus and the shift to the teaching and learning mode of online courses [14]. Since students have more time for self-regulated learning and social media is popular among Generation $\mathrm{Z}$ during the Covid-19 pandemic [2], it is important to explore the potential of using social media for English communication competence acquisition by EFL undergraduate students in the pandemic of Covid-19 situation.

Previously, the most frequently used social media platforms are Facebook, Instagram as well as WeChat and WhatsApp by English language educators, English language teachers as well as college students and college staffs [34,37].However, starting from the year 2019 especially after the outbreak of Covid-19 pandemic, there is a newly emerging popular social-media among youngsters, which is TikTok. TikTok refers to the international version of China's social media platformDouyin with over 2 billion downloads in April 2020 amid Covid-19 pandemic [19]. Douyin is a kind of short video platform which plays 15 to 60 second videos attracting different kinds of people to share their skills, knowledge as well as their experiences. Researchers believe that unique features of TikTok in making short videos easily and its increasing popularity among Generation $\mathrm{Z}$ can be taken into consideration for its potential in English language communication acquisition by EFL undergraduate students in the Covid-19 pandemic or even in the post-pandemic period in the current digital era. So this article will discuss the potentials as well as problems of using TikTok for English language communication competence acquisition by EFL undergraduate students by reviewing previous studies that focused on TikTok and other social media integrated with short-videos in English language communication competence acquisition among youngsters.

\section{Research on the Importance of English Language Communication Competence for EFL Undergraduate Students}

As a group of people who are studying overseas, Chinese international undergraduate students are doing so with the purpose of broadening their horizons as well as improving their English communication competence for the betterment of their future development in the modern digital world with the development of Web-2.0 in the context of Industry 4.0 [46].In accordance with the previous related research in this field, the significance of effective oral English communication skills play critical roles in EFL undergraduate students' international competitive competence in the modern global community as is shown by the demonstration of numerous researchers [7].English language communication competence plays a significant role in EFL undergraduate students' overseas study when studying in English-language medium [6].In this regard, it is crucial for students to master oral English in academic context for the betterment of their academic achievements[29]. Furthermore, students with better speaking skills are more confident in their first year studies and could help reduce their academic pressures of studying in English- medium academic contexts [5] .

On the other hand, the deficiency of oral English language education and lack of exposure to English communication environment for international students from Asian context might negatively affect them as they would have diverse oral communication problems when studying in English-medium higher institutions [42]. A cohort of Asian students encounter many communicative challenges in English language for academic purpose as they are not able to experience the face-to-face communication opportunities due to online learning and remote teaching, which will impede their academic progress[20].The deficiency of oral English competence decreases their confidence and willingness to communicate actively and effectively with lecturers and their peers [42].As they engage in their courses online, they might also be afraid of making mistakes in expressing themselves in English language in avoidance 
of getting negative feedback from others [26].

Compared with traditional face-to-face learning mode, online-learning mode has brought challenges to these students to express their ideas in English language [11].However, even though the online learning and remote teaching can pose challenges to develop their communication skills, it is important to note that the use of digital tools, especially social media platforms, such as TikTok, can also help to alleviate these concerns. Based on the reviewed related literature, there is a lot of potential for social media platforms to help EFL undergraduate students achieve their academic success in their overseas pursuit of their degree with confidence as well as help develop their international competitiveness for the betterment of their future development [5].

\section{Previous Research on the Application of Social Media in English Language Communication}

Numerous studies published have posited that the utilization of social media can help increase English language learners' English proficiency. Zam Zam Al Arif [48] posited that EFL learners showcase positive attitudes towards the utilization of social media in English language learning which can help increase their motivation and willingness in English language speaking and acquisition. Previous studies have also indicated that most of the EFL learners believed that the utilization of social media integrated with short videos can help improve their English communication competence acquisition via self-regulated learning mode with the popular topics shared by English educators [42,39,49].

With the emergence of social media in English education, the most popular social media integrated with short videos used for English communication learning is Facebook[40].Previous researches implemented in Indonesian schools and universities by several scholars posited that the utilization of Facebook in English language education can help improve EFL learners' English proficiency in diverse levels including the four domains, namely reading, writing, speaking and listening by increasing these EFL learners' confidence and willingness in using English as communication tools in internet community[3,17,33,38].Furthermore, other famous social media applications, such as Instagram, WhatsApp, Twitter as well as China-made WeChat and Weiblog also found that the majority of the students show positive attitudes towards the utilization of these social media applications in their English language communication acquisition which can help enhance their interests as well as their motivation to use English for communication purpose in the virtual environment as well as learning English language communication knowledge in an interesting and creative way $[2,4,23,26,47]$.

\section{Potentials of TikTok in English Language Learning and English Language Communication Education for International Undergraduate Students (Generation Z):}

\subsection{Popularity of TikTok among Generation $Z$}

Social media integrated with short videos have its educational function in helping EFL learners improve their English communication competence, especially for college students during the covid-19 pandemic [3].One of the most popularly used social media nowadays is TikTok. $\mathrm{Wu}$ [41] posited that the youngsters aged 30 and below, i.e., generation $\mathrm{Z}$, dominate the major users of TikTok and they spend an average of 52 minutes every day on TikTok. As reported by several studies conducted during the Covid-19 pandemic, the utilization of TikTok among Chinese college students has also increased drastically for whose major user group users are youngsters aged 30 and below [10,43].As such, due to the amount of time spent by these young people, TikTok should be taken into consideration for educational function [38].The explorations of the potential application of TikTok in education field have made success in science education in Indonesian and Indian schools [38].The findings of these previous related research have been indicated that TikTok have helped provide a platform for sharing knowledge as well as educating people with innovative teaching mode enhancing youngsters' learning motivations and interests [43]. Furthermore, TikTok could help provide numerous interactive activities for learners and teachers via short videos. The videos shared by science teachers are employed colourful pictures as well as digital technology to connect the complicated science theories with daily life values. The connections with daily life values make the learning material more vivid and dynamic [38]. So the utilization of TikTok in teaching and learning activities among youngsters could help improve these cohorts of students' learning motivations.

Regarding the aspect of English language communication education, TikTok could supply short videos of English language learning material shared by English teachers as well as English educators or some English native-speakers in its platform for youngsters to learn in an innovative mode [38]. Meanwhile, students can also create their own digital oral English presentations in the form of short videos in TikTok. In this case, teachers as well as some other TikTok users can give comments to help improve these cohort of students' English communication competence by giving comments [48].So EFL learners who use TikTok could acquire English language communication competence via these short videos in English without the limitations of space 
and time[10].Another advantage of the utilization of TIKTOK mobile applications in English education is the length of each video, which is only fifteen seconds contributing to make its excellence in short attention span, and helping EFL youngsters to get the point of the knowledge as well as focus on learning English language communication knowledge effectively.

So the popularity of TikTok among youngsters is one of the reasons why this social media App could be considered as a learning tool for Chinese international undergraduate students during the Covid-19 pandemic. Owing to the specific reasons for Chinese international undergraduate students that English education of China is of bilingual teaching-mode, it is important for these EFL learners to use social media to acquire their English language communication competence by engaging themselves in China-made social media internet community. As the utilization of TikTok has now been a popular culture among youngsters in the current special period of Covid-19.So these EFL young learners can acquire English language communication competence via short videos of TikTok along with recording their own videos in English language and post their own short videos on the TikTok social media platform as a chance to practice their own oral English as well as getting comments from their teachers or their colleagues or other TikTokers via the TikTok.

\subsection{Using TikTok in Teaching English Language Communication Competence}

With the development of Web-2.0 and computer technology, social media applications have now been widely used in education field[4].Specifically the kinds of social media applications integrated with short videos that could help provide interesting mode of learning English language communication competence for EFL language learners in the current digital arena in response to the impacts of Covid-19 pandemic on English language education [39].Previous related studies have indicated the benefits of using social media applications for English language communication education purpose such as Instagram, WhatsApp, Twitter as well as China-made Wechat and Weiblog $[2,4,23,26,47]$.

While studies employing different kinds of research methods having been done in some Asian countries exploring the potential usage of TikTok for English education purpose, the findings of these previous related research have showcased that English language learners hold positive attitudes towards the application of TikTok in English education [17, 25, 16]. However, these studies done in Asian contexts by previous scholars focused mainly on the educational application of TikTok for English language education among primary and secondary school students in classroom learning activities with the guidance of English teachers [30].The authors believe that
TikTok also has potential usage for English language communication competence acquisition by EFL undergraduate students for the reason that oral English proficiency in actual English communicative settings of these students is low [6].And also these previous published articles mainly focus on the potential usage of TikTok in learning English language skills of writing and reading. These previous related researches have posited that students can watch short videos by English teachers of interesting English learning materials of the popular topics among youngsters via TikTok to enhance their vocabulary as well as grammar to improve their English reading and writing skills.

However, the researchers of this article strongly believe that the application of TikTok in English language communication acquisition has its beneficial potentials for EFL undergraduate students for its function as a platform providing chances for short-video-sharing. So English language communication learning materials of the short video form TikTok could be accessible for EFL young learners to improve their English speaking, and listening competences via watching these English learning videos by English teachers or native English speakers. Furthermore, these recorded videos of English learning materials could also help stimulate students' awareness of speaking English by imitating native English speakers [29].

As these kinds of short videos are recorded by native English speakers from western countries, EFL learners can also acquire their social culture knowledge of western countries via watching these recorded videos in TikTok. So there is high significance of using TikTok for English language education in the modern digital arena with the development of Web-2.0 [25]. TikTok is described as a group of Internet-based applications which is built on the ideological and technological foundations of Web 2.0, allowing the creation and exchange of user-generated content [16]. The reason is that TikTok is a platform with short videos which could be regarded as one of the most significant and effective learning resources in the modern digital world in English language education arena [28]. Featuring in short videos, there are numerous English learning videos or some English-speaking countries' TV series shared by TikTok users on TikTok. So EFL young learners can improve their English communication competence via watching these short recorded videos.

From the aspect of motivation, TikTok, with its interesting topics as well as its short-time-consumed features, meets the EFL undergraduate students' need of liking digital vivid pictures with entertainment [31].As youngsters like watching dynamic pictures and listening music, using TikTok in English language communication learning could increase EFL undergraduate students' learning motivations and interests in English language learning [44]. TikTok integrated with short videos could 
help add entertainments to English language communication competence acquisition having been made popular explorations which are seen by numerous English educators as well as English language teachers as powerful drivers of change for teaching and learning practices, in terms of openness, interactivity and sociability [1].Due to these features, traditional learning mode has been broken through. The content of English language is enlarged to diverse domains and is not confined to textbooks. EFL young learners can acquire their English language communication knowledge in diverse aspects.

As a popular culture among youngsters, TikTok has now been a kind of social media integrated with short videos of effective and interesting English language communication learning resources posted by English educators or native English speakers because it has now been welcomed by Chinese EFL learners in English language communication learning in the modern digital English language educational field [19]. TikTok which is integrated with short videos could help give EFL undergraduate students enormous knowledge with its digital material bank data of English language learning materials, instead of traditional class performance. Furthermore, TikTok plays a critical role in English language communication competence acquisition during the pandemic of Covid-19 in the modern digital era with the development of technology, trans-media booming as well as new capital allocation in the new international community. Furthermore, EFL young learners can improve their English language communication competence by watching short videos of English learning materials on TikTok. It is obvious that the utilization of TikTok could help make the English language communication learning activity more dynamic and entertain.

\subsection{Theoretical Implications of Using TikTok's in Teaching English Language Communication Competence}

Canale and Swain [8] proposed the communicative competence theory model, four domains of which are grammatical competence, sociolinguistic competence, discourse competence and strategic competence. In accordance with the proposed communicative competence model by Canale and Swain[8], foreign English language communication learning process needs adequate foreign English language communicative exposures to help enhance foreign language learners' ability of using target foreign language appropriately in actual communicative settings[8].Followed by the communicative competence theory, more and more English linguists as well as English language educators and English language scholars have posited that it is significant for foreign language learners to be immersed in the foreign-target language settings to learn the foreign language well [36].

Due to the outbreak of pandemic of Covid-19, the majority of the higher institutions are closed [27].International education has been negatively impacted by the closure of the higher institutions. And also traditional learning and teaching mode have been changed to online-courses [14].The chances of English language exposure to EFL undergraduate students have been reduced. And also, more self-assigned time are distributed to these youngster. They have more time to spend on social media in the pandemic of covid-19 than ever before [2]. So social media could be used for education purpose in this special period. Furthermore, $\mathrm{Wu}[41]$ indicated that the most popular social media among EFL undergraduate students is TikTok. The authors believe that TikTok could be used by these EFL youngsters to acquire English language communication competence for its increasing popularity among youngsters. Meanwhile, in line with the communicative competence theory, TikTok with short videos could also help increase these youngsters' exposure to English language for its virtual settings in English language [14].So TikTok integrated with short videos could help provide the accessibility to be exposed to English language communicative settings as well as decrease the inconvenience for language learners despite the distance and the settings [30] to help these EFL learners to improve their English language communication competence in the modern digital arena.

\section{Innovative Educational Procedures}

\subsection{Innovative Pedagogical Procedures}

Based on the unique features of the TikTok and its popularity among Z-generations, the researchers believe that TikTok could be regarded as an assessment language tool to assess students' learning outcomes and also could be used as an out-of-class language learning tool to motivate students to focus on their communicative English language learning. In order to help make full use of this language learning tool, the researchers suggest an innovative educational teaching instruction of using the TikTok to support both English teachers and English language learners in oral English teaching and learning in the current situation. It is suggested that the Students who are enrolled in the English Communication course be required to register for the TikTok. The assignments of the English Communication course are composed of two parts. One is the paper-based assignments of reflections after each course for students, and the other is self-recorded English presentation videos by students after each course. The links to the assignments in the TikTok should be shared in the class mobile chat group (i.e., WhatsApp or WeChat). And also, teachers need to use at least three learning sessions to teach students how to use this popular 
online language learning tool and give instructions on how to implement this teaching and learning plan. The innovative teaching procedures are shown as follows.

\section{First step: Familiarization}

During the English language communication courses, students are taught to be familiar with the TikTok language learning tool by watching some sample videos:

1. https://www.youtube.com/watch? $=$ PyaZxrN_gM8.

2. https://www.youtube.com/watch? $v=\mathrm{K} 14 \mathrm{iXhyzC} 7 \mathrm{w}$

(Instructions of making TED Talk on TikTok)

This is where the English teachers give clear instructions on how to download the TikTok and how to use this language learning tool's management of sounds as well as transitions for English language lessons. Students would also be given the chance to test TikTok under their teachers' instructions to master the basic usage of this language learning tool.

\section{Second step: Watching Authentic Samples}

After students master the necessary skills of the use of TikTok, in the second phase, the requirements and evaluation criteria of self-recorded video assignment in TikTok should be assigned to students. In doing so, the English language teacher should first showcase some authentic examples of oral English presentation videos to students:

1. Situational English:

https://www.youtube.com/watch?v=955rL_9ONHs.

2. English Public Speaking:

https://www.youtube.com/watch?v=nP6uCKIXfII

https://www.youtube.com/watch?v=HVx1SDQUXy8

The students should watch the videos and make evaluations of these videos under teachers' guide using the Assessment Sheet (Appendix 1). Students are the divided into several groups for discussion and one leader is selected to share the result of their discussions with the whole class.

\begin{tabular}{|c|c|c|}
\hline $\begin{array}{l}\text { Establishing English } \\
\text { Communicative Competence }\end{array}$ & $\begin{array}{l}\text { Performing English } \\
\text { Communicative } \\
\text { Competence }\end{array}$ & $\begin{array}{l}\text { Creating English } \\
\text { Self-recorded video } \\
\text { Abilities }\end{array}$ \\
\hline $\begin{array}{l}\text {-Content Domain } \\
\text { (content,appearance,organi } \\
\text { zation,accuracy) } \\
\text {-Linguistic Domain } \\
\text { (vocabulary,sentence } \\
\text { structure,rhetorical device) } \\
\text {-Pronunciation } \\
\text { (speed,voice) }\end{array}$ & $\begin{array}{l}\text {-Physical Domain } \\
\text { (gesture,expression, } \\
\text { Eye contact) } \\
\text {-Fluency }\end{array}$ & $\begin{array}{l}\text {-Technical Domain } \\
\text { (sound,camera } \\
\text { shots) } \\
\text {-Originality } \\
\text {-Effects }\end{array}$ \\
\hline
\end{tabular}

Figure 1. Criteria for Developing High-quality English Self-recorded TikTok videos

Third Step: Making Self-recorded Videos using English Language Communication

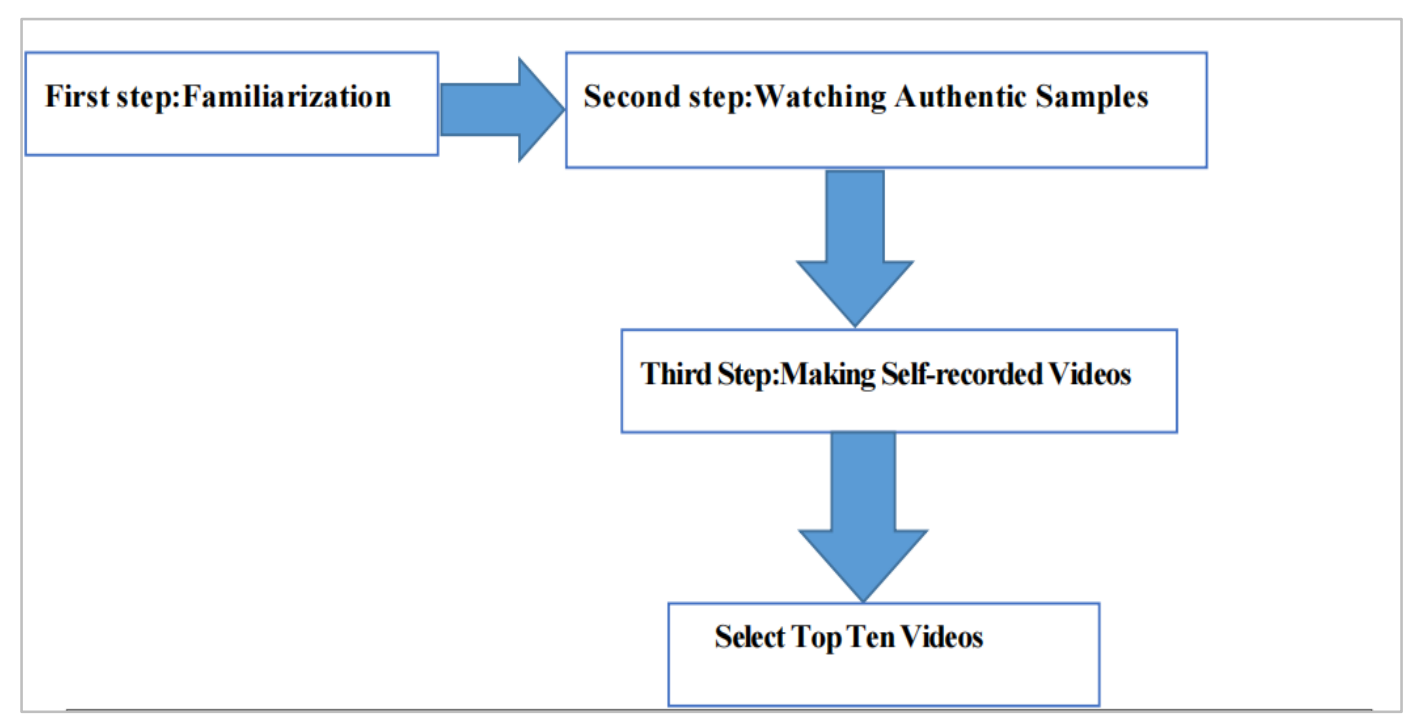

Figure 2. Innovative Pedagogical Procedure of Using TikTok Mobile Video Application 
After mastering the basic skills of using the TikTok tool and watching some samples, students are required to do their first assignment of making English self-recorded videos via the TikTok. The assignment is composed of making a 30 - to 60 -seconds short vide, where the students could select one topic that they have interests in to express in the English language via the TikTok platform. The submitted short videos will be evaluated by teachers following the Assessment Sheet (Appendix A). Students can improve their English language communication competence in accordance with their teachers' comments. The teacher should also encourage all the students to give comments on their classmates' videos and share their comments in class discussions. The purpose of this class activity is to motivate students to improve their English communication via peer feedback. Furthermore, there should be a vote among students to select the top ten best video-makers at the end of the semester to motivate students to fully engaged and make hard efforts in this learning activity. All the students have the right to vote for the top ten video-makers. And the ten winners will get an extra three points to their grade.

\subsection{Innovative Instructions on Making English Self-recorded Videos on TikTok}

The authors also suggest some innovative instructions on how to make English self-recorded videos effectively and accurately. The detailed instructions are shown as follows.

\section{Step 1. Conceptualizing:}

The first step is to conceptualize in which it is composed in establish the plan of self-recorded English TikTok videos. Students can search online to collect materials. Some possible topics could be considered:

1. An introduction to a place

2. Sharing critical ideas towards some issues
3. An introduction to a pet

4. An introduction to a film or a book

Step 2. Brainstorming

The second step is brainstorming where students are required to establish the concept of short videos, such as the content of the video and the presenting method. Students make an English script of their short videos. It is based on the results of the first stage guided by the selected topic.

\section{Step 3. Articulation}

The third step is articulation where students make expressions of their originality and speaking competence. However, articulation is regarded as an action in which students do rehearsal before beginning their speaking activities. This step is to edit the short self-recorded English video before uploading. Students have the chance to make their videos better in linguistic accuracy and content attraction.

\section{Step 4. Monitoring}

In this step, students should monitor the quality of their self-recorded videos. They need to check the accuracy of the video before uploading the video to the TikTok following the Assessment Sheet (Appendix A). Students also should monitor and check the video after uploading their videos.

\section{Step 5. Evaluating}

In this step, the students are required to make self-correction in accordance with the Assessment Sheet (Appendix A). Apart from their own reflections, they could get comments from their teachers and their colleagues in making these self-corrections also. They can improve their videos according to the feedback from their teachers and their classmates. The detailed procedures are showcased below in Table 1. 
Table 1. Procedures of Making Self-recorded English TikTok Videos

\begin{tabular}{|c|c|}
\hline Conceptualizing & $\begin{array}{l}\text { 1.Selecting one topic } \\
\text { 2.Watching authentic samples in similar topics } \\
\text { 3.Planning the content of the video and the designing the presenting } \\
\text { approach } \\
\text { 4.Searching online for collecting relevant materials }\end{array}$ \\
\hline Brainstorming & $\begin{array}{l}\text { 1.Making the outline of the main ideas } \\
\text { 2.Making an English script for the short self-recorded video }\end{array}$ \\
\hline Articulation & $\begin{array}{l}\text { 1.Rehearsing before recording the short English video } \\
\text { 2.Recording the oral English presentation and uploading it to the } \\
\text { TikTok mobile video application after checking. }\end{array}$ \\
\hline Monitoring & $\begin{array}{l}\text { 1.Listening to the self-recorded video before uploading it } \\
\text { 2.Monitoring the self-recorded video from the domains of content, } \\
\text { organization, pronunciation, grammar as well as language usage. }\end{array}$ \\
\hline Evaluating & $\begin{array}{l}\text { 1.Evaluating the self-recorded video in terms of video content, } \\
\text { grammar accuracy,organization as well as language-usage. } \\
\text { 2.Improving the self-recorded videos in accordance with the } \\
\text { Assessment Sheet. }\end{array}$ \\
\hline
\end{tabular}

\section{Issues with TikTok in English Language Learning and English Language Communication Education for EFL Students}

Despite of the above-mentioned positive reports on the application of TikTok in the modern digital English language learning and English language communication education arena, some concerns that need the English language scholars as well as English language teachers to pay attention to still exist. Given the extreme popularity of TikTok among Generation Z, and their international accessibility via the medium of the Internet, these short-videos in English language have neither been explored in greater depth in the English language communication education research nor utilized in a wider academic settings by English experts as well as English educators or English language teachers [10]. And so far, research regarding the application of TikTok in the pandemic of Covid-19 are dominated by researchers in the field of Health Communication [21].There has been very little research investigating the use of short social media videos for English language learning by EFL young learners [9]. Dai and Chen [10] argues that English language educators as well as English teachers have neglected the potential benefits of using TikTok for English education purpose by college students for these cohorts of young people spending a lot of time being exposed to TikTok social media community. TikTok integrated with short videos could make positive contributions to Generation Z' English language communication competence acquisition with attracting EFL young learners' short attention spans and interesting topics among youngsters. More attention should be given by future researchers on the application of TikTok in English language education.

TikTok with numerous interesting short-videos in diverse aspects might distract young students' attention in learning English language for academic purpose. EFL young learners might be attracted by other videos as they are too young to self-regulate themselves effectively for 
academic learning [24]. Furthermore, cyberbullying is still the biggest challenge in using TikTok for English education purpose by young EFL learners[15], because there is no forceful law and effective measures to protect youngster when using TikTok [20]. These young EFL learners are easily abused or bullied in the Cyberspace [2].

Furthermore, [7] stated that there are some potential risks regarding to privacy issues of using social-media for academic purpose among students. It might be unsafe for sharing short-videos in English language by EFL students in public social media space for the purpose of getting comments from their peers or English language experts [3].Posting short self-made short videos in social network communities might cause potential risk for getting attentions from some potential criminals [9].There needs to be more and more effective measures and monitoring mechanism as well as powerful law to be made to protect young internet citizens [9].In conclusion, the application of TikTok in English language education and English language communication competence acquisition is calling for more and more stakeholders to make contributions to establish a wider and more systematic virtual learning system via institutional recognition as well as incorporation along with numerous produced commodities.

\section{Conclusions}

TikTok, as an emerging social media, has now attracted the whole world's attention in different fields for diverse purposes during the pandemic of covid-19. It is undeniable that the popularity of TikTok among Generation $\mathrm{Z}$ is increasing rapidly [7].As the motivation and interests of using TikTok could be transferred into the push-power to engage these young students in their academic study in the modern digital arena, the utilization of TikTok for educational purpose [14], especially for English language communication education purpose should be highlighted by modern English language educators as well as English language teachers in the pandemic of Covid-19 or even in the post pandemic-period. Owing to the development of Web-2.0 and computer technology, English language education as well as international education has been shaped in the modern digital arena. A limited number of research has showcased positive outcomes of using social media in English language education among EFL college students [15].More importantly, social media integrated with short videos have been playing more and more important role in the modern English education field among youngsters $[22,12,15]$.

To conclude, the world has changed rapidly in diverse aspects with the emergence of new digital commodities [17]. TikTok as an emerging technological product has enormous potentials on the modern digital citizens in numerous domains with its popularity among Generation Z. Modern English language teachers, scholars as well as institutions should pay attention to the potential usage of TikTok in English education field for youngsters and also take the chances to create an innovative digital learning system in TikTok for EFL students in the pandemic of Covid-19 or even the post-pandemic period. As what Chomsky (2020) has argued that language educators should make reflections of the new mode of linguistic education in the post-pandemic period, more and more researches on the application of TikTok in English education should be made. 


\section{Appendix A}

Appendix One: TikTok short Video Assessment Sheet

\begin{tabular}{|c|c|c|}
\hline \multirow[t]{2}{*}{$4=$ Excellent } & $1=$ Poor & \multirow[b]{2}{*}{\begin{tabular}{|c|}
$\begin{array}{c}\text { Level } \\
\text { (from } 1 \text { to 4) }\end{array}$ \\
\end{tabular}} \\
\hline & Digital English Communication Competence & \\
\hline Content Domain & $\begin{array}{l}\text { Content: Main ideas of the video are clear. } \\
\text { Organization: Good organizational structure and good fluency. } \\
\text { Visual aids: Visual aids are pertinent to the topic. } \\
\text { Originality: The content of the video should be innovative and attractive. }\end{array}$ & \\
\hline Linguistic Domain & $\begin{array}{l}\text { Vocabulary: The students could employ numerous kinds of vocabulary specific to the topic. Students } \\
\text { could pronounce accurately and speak clearly and loudly. } \\
\text { Sentence Structure: Students could well construct sentences in correct grammar. }\end{array}$ & \\
\hline Physical Domain & $\begin{array}{l}\text { Poise: The student perform with confidence. } \\
\text { Voice: The student's voice is in mild tone -not too loud or too soft. } \\
\text { Gestures: The students could utilize effective gestures to support his/her speech vividly. } \\
\text { Speed: The speed is of appropriateness: not too fast or too slow. }\end{array}$ & \\
\hline Technical Domain & $\begin{array}{l}\text { Sound, music and camera shots: The camera is continuous and focus on the selected topic. The time } \\
\text { is well controlled. } \\
\text { Special effects: Sound effects as well as visual effects should make additions to the mood and content. }\end{array}$ & \\
\hline & TOTAL & \\
\hline
\end{tabular}

\section{Appendix Two:}
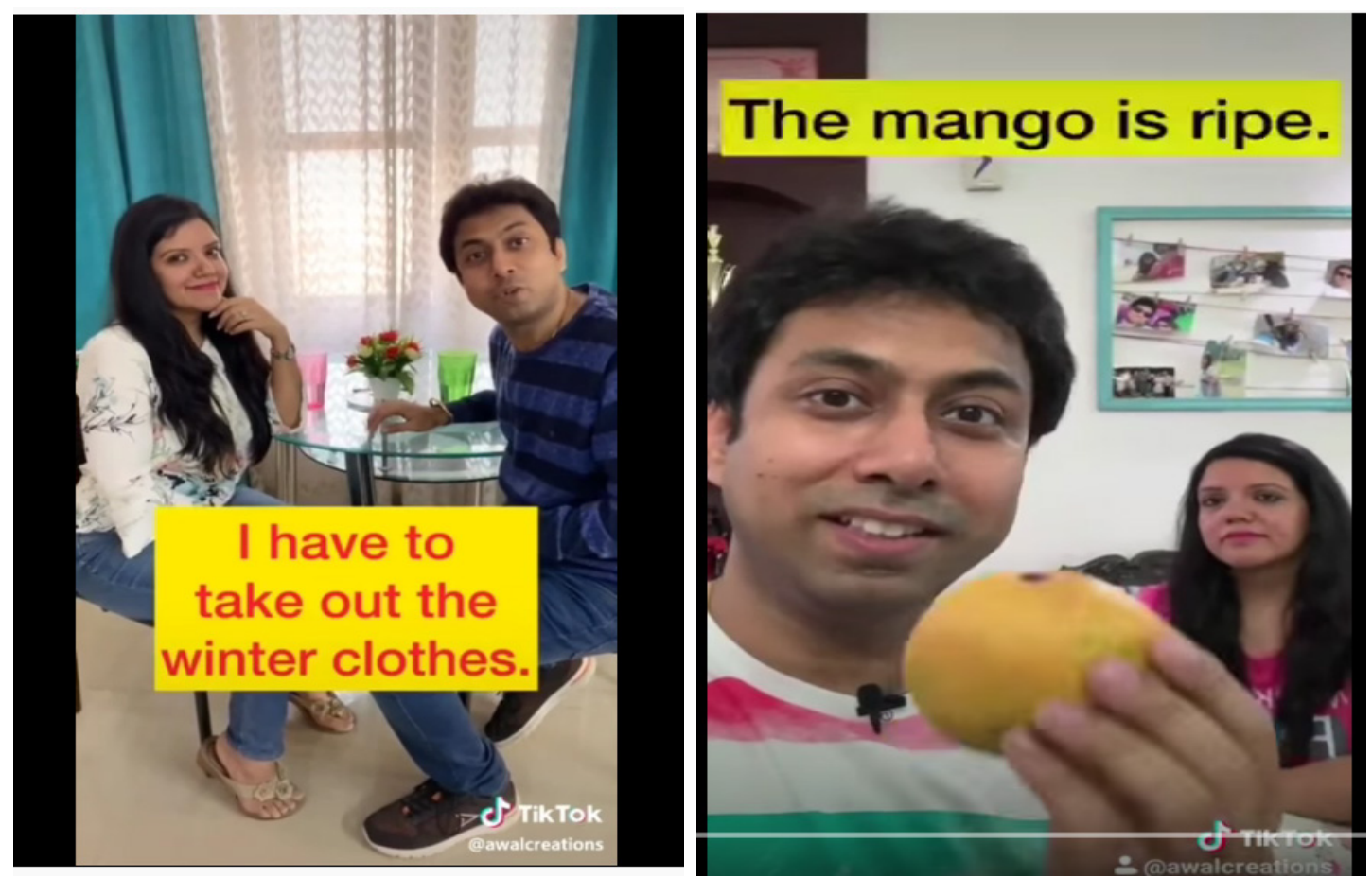

Screenshot from the website: https://www.youtube.com/watch?v=955rL_9ONHs. 


\section{Appendix Three:}

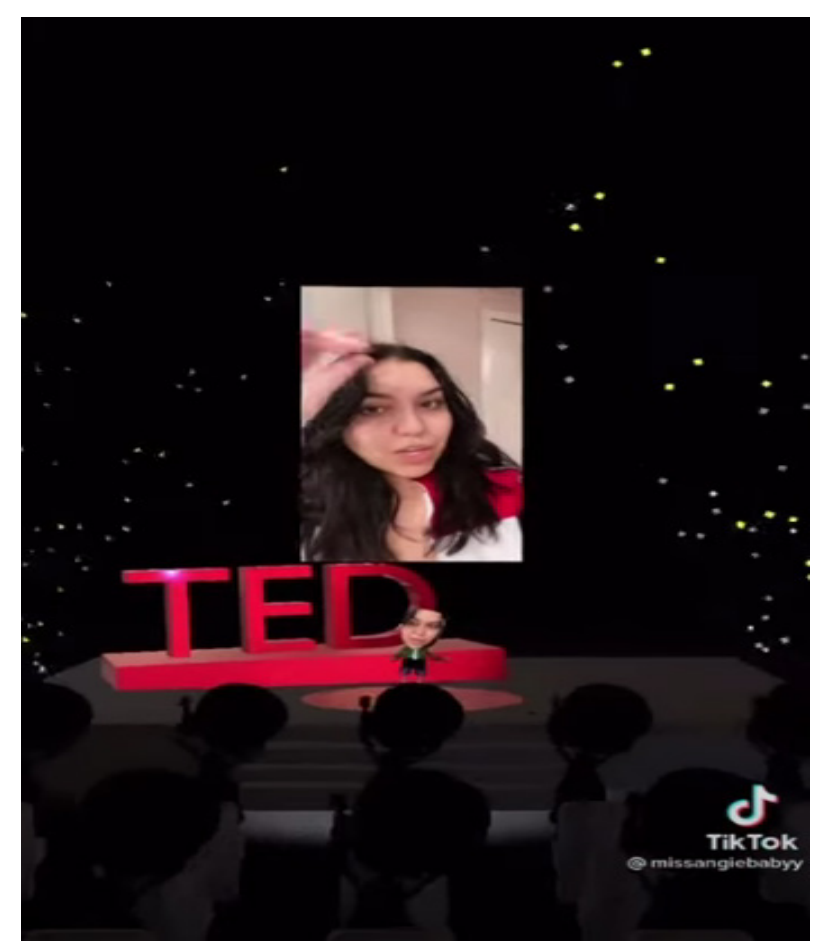

Screenshot from the website:

https://www.youtube.com/watch?v=HVx1SDQUXy8

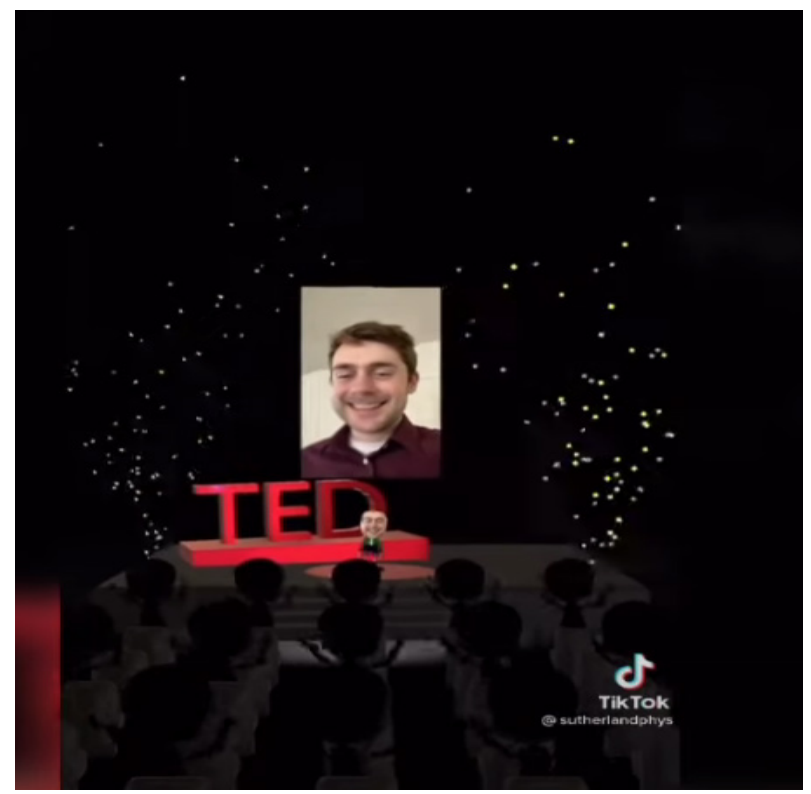

Screenshot from the website:

https://www.youtube.com/watch?v=nP6uCK1XfII

\section{REFERENCES}

[1] Ali Saad Al- Yaari, S. Using Audio-Visual Aids and Computer-Assisted Language Instruction (CALI) to Overcome Learning Difficulties of Speaking in Students of Special Needs. Journal for the Study of English Linguistics,
Vol. 1 no. 2, PP. 231-243, 2013. DOI: 10.5296/jsel.v1i2.4743

[2] Abdulaziz Al Fadda, H. Determining How Social Media Affects Learning English: An Investigation of Mobile Applications Instagram and Snap Chat in TESOL Classroom. Arab World English Journal, Vol. 11 no.1, pp.3-11, 2020. DOI: 10.24093/awej/vol11no1.1

[3] Arfiandhani, P. Utilizing Facebook Groups in Teaching English as Foreign Language: Indonesian EFL Teachers' Voices. International Journal of Language Teaching and Education, Vol.4 no. 1, pp. 53-60, 2020. DOI: 10.22437/ijolte.v4i1.10197

[4] Akkara, S., Anumula, V. S., \& Mallampalli, M. S. (2020). Impact of whatsapp interaction on IMPROVING L2 speaking skills. International Journal of Emerging Technologies in Learning (iJET), Vol.15 no.03, PP. 250-262, 2020. DOI: 10.3991/ijet.v15i03.11534

[5] Aizawa, I., Rose, H., Thompson, G., \& Curle, S. Beyond the threshold: Exploring English language proficiency, linguistic challenges, and academic language skills of Japanese students in an English medium instruction programme. Language Teaching Research, Vol.15 no.03, PP. 240-258, 2020. DOI:10.1177/1362168820965510

[6] Bolton, K., Botha, W., \& Bacon-Shone, J. English-medium instruction in Singapore higher education: policy, realities and challenges. Journal of Multilingual and Multicultural Development, Vol.12 no.5, PP. 250-262, 2017. https://doi.org/10.1080/01434632.2017.1304396

[7] Cao, C., \& Meng, Q. Exploring personality traits as predictors of English achievement and global competence among Chinese university students: English learning motivation as the moderator. Learning and Individual Differences, Vol. 17 no. 03, PP. 250-262, 2020. DOI 10.1016/j.lindif.2019.101814

[8] Canale, M., \& Swain, M. Theoretical bases of communicative approaches to second language teaching and testing. Applied Linguistics, Vol. I no.1, pp. 1-47, 1980. DOI:10.1093/applin/i.1.1

[9] Chakuzira, W., \& Kadyamatimba, A. The perceived benefits and barriers to the application of mobile and social networking technologies in higher learning institutions. Problems and Perspectives in Management, Vol.15 no.3, pp. 343-351, 2017. DOI:10.21511/ppm.15(3-2).2017.04

[10] Dai, L., \& Chen, P. Reasons for the popularity of TikTok, the shortages and the ways forward. Proceedings of the 2019 3rd International Seminar on Education, Management and Social Sciences (ISEMSS 2019), Vol. 15 no.3, pp. 1216,2019. DOI: $10.2991 /$ isemss-19.2019.105

[11] .Daniel, S. J. Education and the COVID-19 pandemic. Prospects, Vol. 49 no. 1, pp. 91-96, 2020. DOI: $10.1007 / \mathrm{s} 11125-020-09464-3$

[12] .Dayu, A. T.The teaching strategy for teaching English guidance And Counseling by using Facebook group in Indonesia. Intensive Journal, Vol.1 no. 2, pp 131-143, 2018. DOI:10.31602/intensive.v1i2.1528

[13] .DeVries, R. Vygotsky, Piaget, and Education: a reciprocal assimilation of theories and educational practices. New Ideas in Psychology, Vol.18 no. 2, pp. 187-213, 2000. 


\section{DOI:10.1016/s0732-118x(00)00008-8}

[14] Escamilla-Fajardo, P., Alguacil, M., \& López-Carril, S. Incorporating TikTok in higher education: Pedagogical perspectives from a corporal expression sport SCIENCES COURSE. Journal of Hospitality, Leisure, Sport \& Tourism Education, Vol.1 no. 2, pp. 12-14, 2021. DOI: 10.1016/j.jhlste.2021.100302

[15] Faryadi, Q. Effectiveness of Facebook in English Language Learning: A Case Study. OALib, Vol.04 no. 11, pp. 1-11, 2017. DOI:10.4236/oalib.1104017

[16] Fahdin, R. G. Student's perception toward the use of TikTok in learning English vocabulary. Khazanah: Jurnal Mahasiswa, Vol.12 no. 2, pp. 12-14, 2020. DOI: 10.20885/khazanah.vol12.iss2.art47

[17] Haerazi, H., Utama, I. M., \& Hidayatullah, H. Mobile Applications to Improve English writing skills viewed from critical thinking ability for pre-service teachers. International Journal of Interactive Mobile Technologies (iJIM), Vol.14 no. 7, pp 58-64, 2020. DOI:10.3991/ijim.v14i07.11900

[18] Hymes, D., Lyons, J., \& Kermode, F.A review of Lyons, Noam Chomsky. Noam Chomsky: Critical Assessments. Language, Vol.48 no. 2, pp. 416-427, 1972. DOI:10.2307/ 412143

[19] Kaye, D. B., Chen, X., \& Zeng, J. The co-evolution of two Chinese mobile short video apps: Parallel Platformization of Douyin and TikTok. Mobile Media \& Communication, Vol.8. no.2, pp. 340-335, 2020. DOI:10.1177/2050157920 952120

[20] Liu, N., Lin, C., \& Wiley, T. G. Learner views on English and English language teaching in China. International Multilingual Research Journal, Vol.10. no.2, pp137-157, 2016. DOI: 10.1080/19313152.2016.1147308

[21] Liu, Q., Zheng, Z., Zheng, J., Chen, Q., Liu, G., Chen, S., Ming, W. Health communication through news media during the early stage of the COVID-19 outbreak in China: DIGITAL topic modeling approach. Journal of Medical Internet Research, Vol.22 no.4, pp. 59-62, 2020. DOI: $10.2196 / 19118$

[22] Mallawaarachchi, C. The positive impact in changing of e-learning environment to m-learning to enhance critical thinking skills in foreign language learning. Proceedings of the 5th International Conference on Frontiers of Educational Technologies - ICFET Vol.22 no.4, pp. 59-62,2019. DOI:10.1145/3338188.3338206

[23] Madzlan, N. A., Seng, G. H., \& Kesevan, H. V. Use of video blogs in Alleviating public speaking anxiety Among ESL learners. Journal of Education and E-Learning Research, Vol.7 no.1, p p 93-99, 2020. DOI: 10.20448/journal.509.2020.71.93.99

[24] McLoughlin, C., \& Lee, M. J. W. (2010). Personalised and self-regulated learning in the Web 2.0 era: International exemplars of innovative pedagogy using social software. Australasian Journal of Educational Technology, Vol. 26 no.1, pp. 12-15. DOI:10.14742/ajet.1100

[25] Md Yunus, M., Zakaria, S., \& Suliman, A. The Potential Use of Social Media on Malaysian Primary Students to Improve Writing. International Journal of Education and
Practice, Vol.7 no.4, pp. 450-458, 2019. DOI: 10.18488/journal.61.2019.74.450.458

[26] Montaner, S. EFL written competence through Twitter in mobile version in compulsory secondary education. Global Journal of Foreign Language Teaching, Vol.10 no.2, pp 101-110, 2020. DOI:10.18844/giflt.v10i2.4665

[27] Mok, K. H., Xiong, W., Ke, G., \& Cheung, J. O. Impact of COVID-19 pandemic on International higher education and student mobility: Student perspectives from mainland China and Hong Kong. International Journal of Educational Research, Vol.105, no. 101718, pp. 34-36, 2021. DOI:10.1016/j.ijer.2020.101718

[28] Nabilah, A., M.P, D. L., Lazuwardiyyah, F., Syaifuddin, S., \& Abdi, W. M. (2021). Students' perception toward the use of TikTok video in learning writing descriptive text at MAN 1 Gresik. Journal of Research on English and Language Learning (J-REaLL), Vol.2, no.1, pp. 164-177, 2021. DOI:10.33474/j-reall.v2i1.9017

[29] Nam Hee Kim, \& Mie Ae Jung. Korean EFL College Students' use of Listening strategies for oral communication in English. Studies in English Language \& Literature, Vol. 43 no. 3, pp109-142, 2017. DOI: 10.21559/aellk.2017.43.3.006

[30] Nariyati, N. P., Sudirman, S., \& Pratiwi, N. P. EFL Pre-Service Teachers' perception toward the use of Mobile assisted language learning in teaching english. International Journal of Language Education, Vol.4 no.2, pp38-42, 2020. DOI:10.26858/ijole.v4i2.10052

[31] Poramathikul, P., Arwedo, N., Abdulhakim, I., \& Wattanaruwangkowit, P. The influence of using social media as a learning platform by bilingual and Multilingual learners on English speaking skills. English Language in Focus (ELIF), Vol.2 no.2, pp. 111-121, 2020. DOI: 10.24853/elif.2.2.111-122

[32] Puimom, S. Enhancing students' motivation: Speaking challenging clips via Facebook. International Journal of Scientific and Research Publications (IJSRP), Vol.10 no.7, pp. 443-450, 2020 DOI:10.29322/ijsrp.10.07.2020.p10352

[33] Putrawan, G. E., \& Riadi, B. English as a foreign LANGUAGE (efl) Learners' predominant language use for Online informal learning activities through smartphones in Indonesian Context. Universal Journal of Educational Research, Vol.8 no. 2, pp. 695-699, 2020. DOI: 10.13189/ujer.2020.080243

[34] Sha, P., Sariyska, R., Riedl, R., Lachmann, B., \& Montag, C. Linking internet communication and smartphone use disorder by taking a closer look at the Facebook and WhatsApp applications. Addictive Behaviors Reports, Vol.9 no. 2, pp. 100-148, 2020. DOI:10.1016/j.abrep.2018. 100148

[35] Shadiev, R., Hwang, W., \& Huang, Y. Review of research on mobile language learning in authentic environments. Computer Assisted Language Learning, Vol.30 no.3, pp 284-303, 2017. DOI: 10.1080/09588221.2017.1308383

[36] Sobaih, A. E. E., Hasanein, A. M., \& Abu Elnasr, A. E. Responses to COVID-19 in Higher Education: Social Media Usage for Sustaining Formal Academic Communication in Developing Countries. Sustainability, Vol.12 no.16, pp650-665, 2020. DOI:10.3390/su12166520 
[37] Sri Kuning, D. Applications of social media to Learn Speaking. Edukasi Lingua Sastra, Vol.18 no.1, pp. 77-85, 2020. DOI:10.47637/elsa.v18i1.227

[38] Syah, R. J., Nurjanah, S., \& Mayu, V. P. A. Tikio (TikTok App Educational Video) Based on the Character Education of Newton's Laws Concepts Preferred to Learning for Generation Z. Pancaran Pendidikan, Vol.9 no.4, pp. 132-143, 2020. DOI:10.25037/pancaran.v9i4.325

[39] Using Social Media for Learning in High Schools: A Systematic Literature Review. European Journal of Educational Research, Vol.9 no.2, pp. 12-16, 2020. DOI:10.12973/eu-jer.9.2.889

[40] Wongsa, M., \& Son, J. Enhancing Thai secondary school Students' English speaking skills, attitudes and motivation with drama-based activities and Facebook. Innovation in Language Learning and Teaching, Vol.15 no.2, pp. 103-194, 2020. DOI:10.1080/17501229.2020.1853134

[41] $\mathrm{Wu}, \mathrm{L}$. Comparative analysis of Video stories and user behaviors on WeChat And TikTok. Proceedings of the 2020 $3 r d$ International Conference on Humanities Education and Social Sciences (ICHESS 2020). Vol.13 no.2, pp113-124, 2020. DOI:10.2991/assehr.k.201214.518

[42] Xiong, Y., \& Zhou, Y. Understanding East Asian Graduate Students' Socio-cultural and Psychological Adjustment in a U.S. Midwestern University. Journal of International Students, Vol.8 no.2, pp. 769-794, 2018. DOI:10.32674/jis.v8i2.103

[43] Xu, L., Yan, X., \& Zhang, Z. Research on the causes of the
"TikTok" app becoming popular and the existing problems. Journal of Advanced Management Science, Vol.7 no.2, pp. 59-63, 2019. DOI:10.18178/joams. 7.2.59-63

[44] Yang, D. A research review of college English Audio-Visual Speaking teaching in China in Multi-Modality symbol framework. English Language and Literature Studies, Vol. 9 no.4, pp39-43,2019.DOI:10.5539/ells.v9n4p39

[45] Yang, Z. A study on self-efficacy and its role in mobile-assisted language learning. Theory and Practice in Language Studies, Vol.10 no.4, pp. 439-452, 2020. DOI: $10.17507 /$ tpls. 1004.13

[46] Zhao, K. Made in contemporary China: exploring the national identity of Chinese international undergraduate students in the US. Studies in Higher Education, Vol.45 no.12, pp. 2451-2463, 2019. DOI: 10.1080/03075079.201 9.1615046

[47] Zhou, L., Xi, Y., \& Lochtman, K. The relationship between second language competence and willingness to communicate: The moderating effect of foreign Language Anxiety. Journal of Multilingual and Multicultural Development, Vol.43 no.11, pp. 1-15, 2020 DOI:10.1080/01434632.2020.1801697

[48] Zam Zam Al Arif, T. The Use of Social Media For English Language Learning: An Exploratory Study of EFL University Students. Metathesis: Journal of English Language, Literature, and Teaching, Vol.3 no.2, pp. 224 233, 2019. DOI:10.31002/metathesis.v3i2.1921 